\title{
Textural and Petrological Variation Within the Crater Facies Kimberlite Bodies of the Fort à la Corne Province, Saskatchewan, Canada
}

Brown, J.W. and Butcher, A.R.

Camborne School of Mines, University of Exeter, Redruth, Cornwall, TR15 3SE, United Kingdom

The kimberlite bodies of the Fort à la Corne province, in central Saskatchewan, were identified under $100 \mathrm{~m}$ of glacial overburden by geophysical methods in 1988, and were confirmed by drilling in 1989 (Lehnert-Thiel et al., 1992). Significant amounts of gem quality diamonds have been recovered but no horizons of economic grade have been determined as yet. Large diameter drilling evaluation of these deposits is currently ongoing by the Fort à la Corne joint venture (consisting of Uranerz Exploration and Mining Ltd., Cameco Corp., Monopros Ltd. And Kensington Resources).

The Fort à la Corne kimberlite province consists of more than seventy separate kimberlite bodies within an area of $30 \times 45 \mathrm{~km}$, apparently making it one of the largest kimberlite fields in the world (Scott-Smith et al., 1994). The morphology of the Fort à la Corne kimberlites differs significantly from the majority of other kimberlites, both in Canada and world wide, in that they are saucer-shaped (ScottSmith et al., 1994) kimberlite crater facies, as opposed to the classic flared, carrotshaped diatremes of kimberlites in southern Africa. This unusual morphology provides diameters of up to $1600 \mathrm{~m}$ with depths greater than $250 \mathrm{~m}$. Whilst the crater facies of the Fort à la Corne kimberlites have been preserved and sampled, there has been no drilling intersection of diatreme facies at depth. There does not appear to be any form of diatreme development at the centre of the circular geophysical anomalies produced by the separate bodies. The Fort à la Corne kimberlites have been stratigraphically constrained as being late Cretaceous in age.

Petrographic analysis of samples taken from eight of the Fort à la Corne bodies has identified a variety of textural and mineralogical facies present both within and between the different bodies. This intra- and inter-kimberlite petrographic variation of these kimberlites suggests that there were different eruptive processes occurring during the emplacement of the Fort à la Corne province. The most obvious variations are in the size and abundance of various mantle phases, e.g. macrocrystic olivine, garnets etc; and the differing abundance, size, and textural habit of a lapilli phase. This study, which is part of a $\mathrm{PhD}$ thesis, has catalogued and correlated these different facies, and then utilised the results on order to consider their petrogenesis.

Olivine is the most abundant mineral throughout all of the intervals observed within all eight bodies. It ranges in abundance from $\sim 50$ to $>80$ modal \%, and in size from $<0.5 \mathrm{~mm}$ euhedral phenocrysts to $>5 \mathrm{~mm}$ rounded and/or fragmental macrocrysts. Olivine occurs in two textural habits: within lapilli; and within the inter-lapilli groundmass/matrix interstitial phase. The lapilli are easily differentiated by their fine- 
grained, melanocratic groundmass that is much darker than the material that is interstitial to the lapilli. The lapilli display a variety of textural forms, which range from: amoeboid lapilli with irregular-curvilinear margins; to rounded lapilli (some of which appear to have a concentric arrangement of phenocrysts); through to lapilli with angular margins.

The other major primary mineral phases encountered within the Fort à la Corne kimberlites are pyrope garnets, phlogopite mica and opaque phases consisting of chromites and ilmenites. There appears to be a paucity of any fresh clinopyroxene. There are numerous alteration assemblages including various forms of serpentine, amorphous and pervasive vein carbonate, and amorphous magnetite. These assemblages are predominantly found within the material that is interstitial to the lapilli and crystalline phases. All the crystalline phases present display extensive alteration, and some have been completely pseudomorphed by secondary minerals. This gross pervasive alteration has also obliterated the lapilli from some intervals. Within individual thin-sections that display extensive alteration products, there are, paradoxically, juxtaposed examples of olivine which have intact remnant cores that are suitable for EPMA (Electron Probe Micro-Analysis).

There appear to be two major, Group 1 kimberlite, petrographic facies within the eight bodies observed. There is a coarser-grained $(2-5 \mathrm{~mm})$ lapilli-dominated pyroclastic kimberlite, and a finer $(<2 \mathrm{~mm})$ olivine crystal-dominated pyroclastic kimberlite. The former facies has greater abundances of macrocrystic olivine, garnet, phlogopite and opaques often within lapilli, or with evidence of a lapilli selvage. With the exception of the phlogopite, these macrocrystic components often have an angular or fragmental habit. The latter facies have fewer macrocrystic minerals and are dominated by finer-grained euhedral olivine crystals and phlogopite laths; these facies also have a greater incidence of small $(<0.5 \mathrm{~mm})$ euhedral opaques within the interstitial phase.

This present-day morphology and preservation of the Fort à la Corne deposits is thought to reflect the geological environment at the time of emplacement (Scott-Smith et al., 1994). The observations drawn from this petrological investigation have been considered with respect to the unusual morphology of the host bodies and their apparent lack of a diatreme phase. The subsequent conclusions drawn have been used to posit an emplacement mechanism that could produce the petrographic variation detailed within the enigmatic kimberlite bodies of the Fort à la Corne province.

\section{References}

Lehnert-Thiel K., Loewer R., Orr R.G. and Robertshaw P., 1992, Diamond-bearing kimberlites in Saskatchewan, Canada: The Fort à la Corne case history: Explor. Mining Geol. Vol.1 no 4 p. 391-403.

Scott-Smith, B.H., Orr, R.G., Robertshaw, P., and Avery, R.A., 1994. Geology of the Fort à la Corne kimberlites, Saskatchewan: Proc. CIM District 6 Meeting, Vancouver, Canada, p. 19-24. 